\title{
Botanical aspects of Heteropterys umbellata (Malpighiaceae): a cytological and palynological approach
}

\author{
SAULO M. SOUSA ${ }^{1}$, ARYANE C. REIS ${ }^{1}$, SHAIANY S.L. GOMES ${ }^{1}$, KARINA B. BERNARDO ${ }^{2}$, \\ FÁTIMA R.G. SALIMENA ${ }^{3}$ and LYDERSON F. VICCINI ${ }^{1}$ \\ ${ }^{1}$ Instituto de Ciências Biológicas, Departamento de Biologia, Laboratório de Genética \\ Universidade Federal de Juiz de Fora (UFJF), Campus Universitário, Bairro Martelos \\ 36036-900 Juiz de Fora, MG, Brasil \\ ${ }^{2}$ Empresa Brasileira de Pesquisa Agropecuária, Centro Nacional de Pesquisa de Gado de Leite \\ Rua Eugênio do Nascimento, 610, Dom Bosco, 36038-330 Juiz de Fora, MG, Brasil \\ ${ }^{3}$ Instituto de Ciências Biológicas, Departamento de Botânica, Universidade Federal de Juiz de Fora (UFJF) \\ Campus Universitário, Bairro Martelos, 36036-900 Juiz de Fora, MG, Brasil \\ Manuscript received on September 17, 2009; accepted for publication on August 11, 2010
}

\begin{abstract}
The genus Heteropterys is one of the major genera in Malpighiaceae. However, few cytological and palynological studies were reported. The present work described for the first time the chromosome number, heterochromatin pattern, meiotic behavior, pollen viability and palynological aspects of Heteropterys umbellata, a very spread species. One large Brazilian population was evaluated using conventional techniques for meiotic studies and acetolyse to access the pollen morphology. The species showed $2 \mathrm{n}=20$ chromosomes, normal meiotic development and viable pollens. Great blocks of heterochromatin were observed around the centromers. DAPI staining was positive for centromeric heterochromatin, while $\mathrm{CMA}_{3}$ mark was observed just at terminal regions of one pair of homologues chromosomes. This result and the presence of one chromosome pair attached to the nucleoli during the pachytene and diakinesis suggested the presence of only one pair of NORs. Palynological analysis revealed that pollen grains are apolar, 6 porate and with colpoids associated to all pores. The pollen content was positive for the starch test, and the exine was rugulate with little psilate regions.
\end{abstract}

Key words: chromosome number, heterochromatin pattern, Heteropterys umbellata, Malpighiaceae, meiosis, pollen viability.

\section{INTRODUCTION}

The genus Heteropterys Kunth is one of the major genera in the Malpighiaceae family, followed in size Byrsonima, which is slightly smaller. With nearly 130 species found in different habitats, the species are distributed from the savannas and dry woodlands to rain forests in the New World tropics and subtropics, from northern Mexico and the West Indies to northern Argentina and southeastern Brazil, and can be also found at low wet

Correspondence to: Saulo Marçal de Sousa

E-mail: saulo_marcal@yahoo.com.br places along the coast of West Africa from Senegal to Angola (Anderson 1993, Amorim 2002).

As well as other genera in Malpighiaceae, Heteropterys has each cincinnus reduced to one flower and dry schizocarpic fruits. The genus is defined by the presence of samaras, which are unique in the family. While in most Malpighiaceae genera the samaras have a dominant dorsal wing, thickened along the upper (adaxial) margin, and the parallel veins bend downward ending in the thinner abaxial margin, in Heteropterys the situation is reversed, with their adaxial margin being thinner than the abaxial one, and the wing bends more or less 
upward, with the veins following this curvature (Amorim 2002).

The taxonomy of Heteropterys is very complex, and innumerous approaches have been used to support inclusions in the genus and also in the Malpighiaceae family. In spite of the dorsal-winged samara, the overall morphology suggests that this genus is actually more closely related to genera with lateral wings, such as Tetrapterys, than to the large group with the usual type of dorsal-winged samara as Stigmaphyllon and Banisteriopsis, for example (Anderson and Davis 2007). Studies regarding chromosome number and karyotype have also helped the characterization of some clades in Malpighiaceae; nevertheless, few data about cytology of Heteropterys were observed. Only nine species have the chromosome number reported, and $\mathrm{n}=10$ was observed for most of them. Other haploid numbers were observed: $\mathrm{n}=17$ for $H$. angustifolia and $\mathrm{n}=21,28$ and 29 for H. leona (Pal 1964, Semple 1970, Ormond et al. 1981, Anderson 1990, Lombello and Forni 2001).

The determination of chromosome number in plants is a critical step to detect processes that make feasible abrupt speciation such as polyploidy, aneuploidy and dysploidy (Briggs and Walters 1997, Guerra 2008). Moreover, the knowledge of chromosome number and morphology, plus the meiotic behavior, may help to differentiate between allopolyploidy or autopolyploidy considering the differences or similarities among the involved genomes (Stebbins 1971, Guerra 2008). Complementarily, the behavior of the chromosomes at meiosis can affect pollen viability. If meiosis is irregular, with the chromosomes pairs segregating abnormally, the sterility of the pollen grain can be expected to occur due to cytological reasons. Nevertheless, if meiosis is normal, other mechanisms as inbreeding depression, pollen age and its exposure to environmental stress such as temperature and humidity, can be the causes of pollen sterility in one species (Krebs and Hancock 1990, Willis 1993, Husband and Schemske 1996, Goodwillie 2000, Boff and Schifino-Wittmann 2002).

Besides the chromosome counts, other chromosome markers such as C-banding, Ag-NOR and fluorescent staining methods performed with counter-staining reagents are useful to obtain species-distinctive regions of chromosomes. They can also be applied to cytotaxon- omy and chromosome evolution, including the comparison among individuals of the same species distributed into and among different populations (Kokubugata and Katsuhiko 1996, Sousa et al. 2009).

Among the Heteropterys species, Heteropterys umbellata Adr. Juss. is a widespread species that can be found at Brazilian savannas and can be also confused with H. glabra Hook \& Arn., another similar but different species used in Brazilian folk medicine as a sedative and anxiolytic agent (Galietta et al. 2005). Many authors classified both species as synonyms due to their morphological similarity and probably also due to the lack of reports about other botanical basic aspects. So, additional data are necessary for an accurate conclusion about the correct status of this species and the genus.

The present work reported the chromosome number, the meiotic behavior and the heterochromatin patterns in H. umbellata. The palynomorphology and pollen viability were also showed.

\section{MATERIALS AND METHODS}

\section{BiologicAl MATERIAL}

Immature inflorescences of 30 individuals were collected from one population of $H$. umbellata at Diamantina, Minas Gerais State, Brazil. Inflorescences were fixed in fresh cold methanol: acetic acid solution 3:1 for at least 24h. Vouchers were housed at the Herbarium CESJ of Universidade Federal de Juiz de Fora, Juiz de Fora, Minas Gerais, Brazil.

\section{PRE-SELECTION OF INFLORESCENCES}

In order to obtain suspensions with meiotic stage cells appropriate to chromosome counts and analyses of meiotic behavior, the immature inflorescences were separated into arbitrary sizes, and the cells of each one were observed. Cell suspensions were made based on the previously defined size that showed meiotic cells in different stages of development.

\section{Cell Suspensions and Slides Preparation}

The cell suspensions were prepared according to Viccini et al. (2005) with some modifications. Nearly 40 anthers were excised from 12 flower buds and placed in a special microtube $(0.5 \mathrm{ml})$ with a nylon screen attached $(60 \mu \mathrm{m})$. 
The material was washed in distilled water to remove fix solution. The tube containing the anthers was immersed in enzymatic solution (Pectinex Novozymes, Bagsvaerd, Denmark $^{\circledR}$ ) and incubated at $34^{\circ} \mathrm{C}$ for $20 \mathrm{~min}$. After enzymatic maceration, the anthers were washed in distilled water and mechanically fragmented to remove the pollen mother cells (PMCs). The obtained cellular suspension was centrifuged at 2000rpm for $12 \mathrm{~min}$. For slides preparation, drops of the suspension were added to clean slides. Following this step the slides were airdried and stained with Giemsa solution for three min. Cell images were analyzed using Image Pro Plus software (Media Cybernetics ${ }^{\mathrm{TM}}$, Silver Spring. MD, USA). At about 20 suspensions containing a mix of buds from all individuals were obtained. Around 12 slides were prepared from each suspension.

\section{Chromosome BANDing}

For heterochromatin studies, the C-banding procedure was performed according to Schwarzacher et al. (1980) with minor modifications. Aged slides (3 days) were hydrolyzed in acetic acid $45 \%\left(60^{\circ} \mathrm{C}\right)$ for $12 \mathrm{~min}$ and, then, immersed in $5 \% \mathrm{Ba}(\mathrm{OH})_{2}$ at $28^{\circ} \mathrm{C}$ for $10 \mathrm{~min}$. After that, the slides were incubated in $2 \times \mathrm{SSC}$ at $60^{\circ} \mathrm{C}$ for $80 \mathrm{~min}$, and stained with a $10 \%$ Giemsa solution for $30 \mathrm{~min}$. The fluorochrome staining was performed according to Schweizer (1976). Aged slides (3 days) were doubled-stained with $0.5 \mathrm{mg} / \mathrm{mL}$ of chromomycin A3 (CMA) (90 $\mathrm{min}$ ) and $2 \mu \mathrm{g} / \mathrm{mL}$ of diamidino-2-phenylindole (DAPI) (30 min), and immediately mounted in 1:1 (v/v) Mcllvaine's pH 7.0 bufer-glycerol. Slides were aged for 3 days before analysis, and the chromosomes were observed using an epifluorescence microscope (Olympus BX 51) with appropriate filter set.

\section{Pollen Viability}

Mature flower buds were collected and used to prepare the slides by squash technique. The viability was estimated according to differential staining (Alexander 1980). Digital images were taken with the BX 51 microscope and analyzed using Image Pro Plus software (Media Cybernetics $^{\mathrm{TM}}$, Silver Spring. MD, USA). At about 20,000 grains were analyzed from 10 slides.

\section{PALYNOLOGY}

Mature anthers were placed in glacial acetic acid for at least $24 \mathrm{~h}$ and then acetolysed according to Erdtman (1960). The slides were mounted in glycerin jelly and examined using a BX 51 Olympus microscopy. The images were analyzed using Image Pro Plus software (Media Cybernetics $^{\mathrm{TM}}$, Silver Spring. MD, USA). The material and the slides were stored at the Biology Department of Federal University of Juiz de Fora, Juiz de Fora, Minas Gerais State, Brazil. At least 20 slides were prepared, and measures of pollen diameters were obtained from at least 20 grains per slide, while for other characters about 10 grains were used per slide. The pollen classifications were made according to Punt et al. (2007).

\section{Pollen Hystochemistry}

Pollen grains were stained with Lugol (starch indicator) and with Sudan (lipids indicator) according to Baker and Baker (1979). Around 10 slides were prepared: one half was stained with Lugol and the other with Sudan. The slides stained with Lugol and Sudan were compared with slides not stained using a BX 51 Olympus microscopy. The results were registered and analyzed using Image Pro Plus software (Media Cybernetics ${ }^{\mathrm{TM}}$, Silver Spring. MD, USA).

\section{RESULTS}

\section{Chromosome Number and Meiotic Behavior}

The analysis of meiotic behavior of $H$. umbellata showed regular chromosome pairing and normal stage cells: interphase, zygotene, pachytene, initial diplotene, diplotene, diakineses, metaphase I, anaphase I, telophase I, metaphase II, anaphase II and telophase II (Fig. 1). Ten bivalents were observed during pachytene, diplotene and diakinesis in all the studied individuals, which indicates that the chromosome number of the species is $2 n=20$.

Although we have been observed a normal chromosomal behavior during meiosis, little meiotic alterations as translocations, precocious migration, laggard chromosomes and chromosome bridges were also observed (Fig. 2 A-D). Considering meiosis I, laggard chromosomes were found in $11.20 \%$ of the cells, chromosome bridges in $13.21 \%$, translocations in $7.36 \%$ and only 

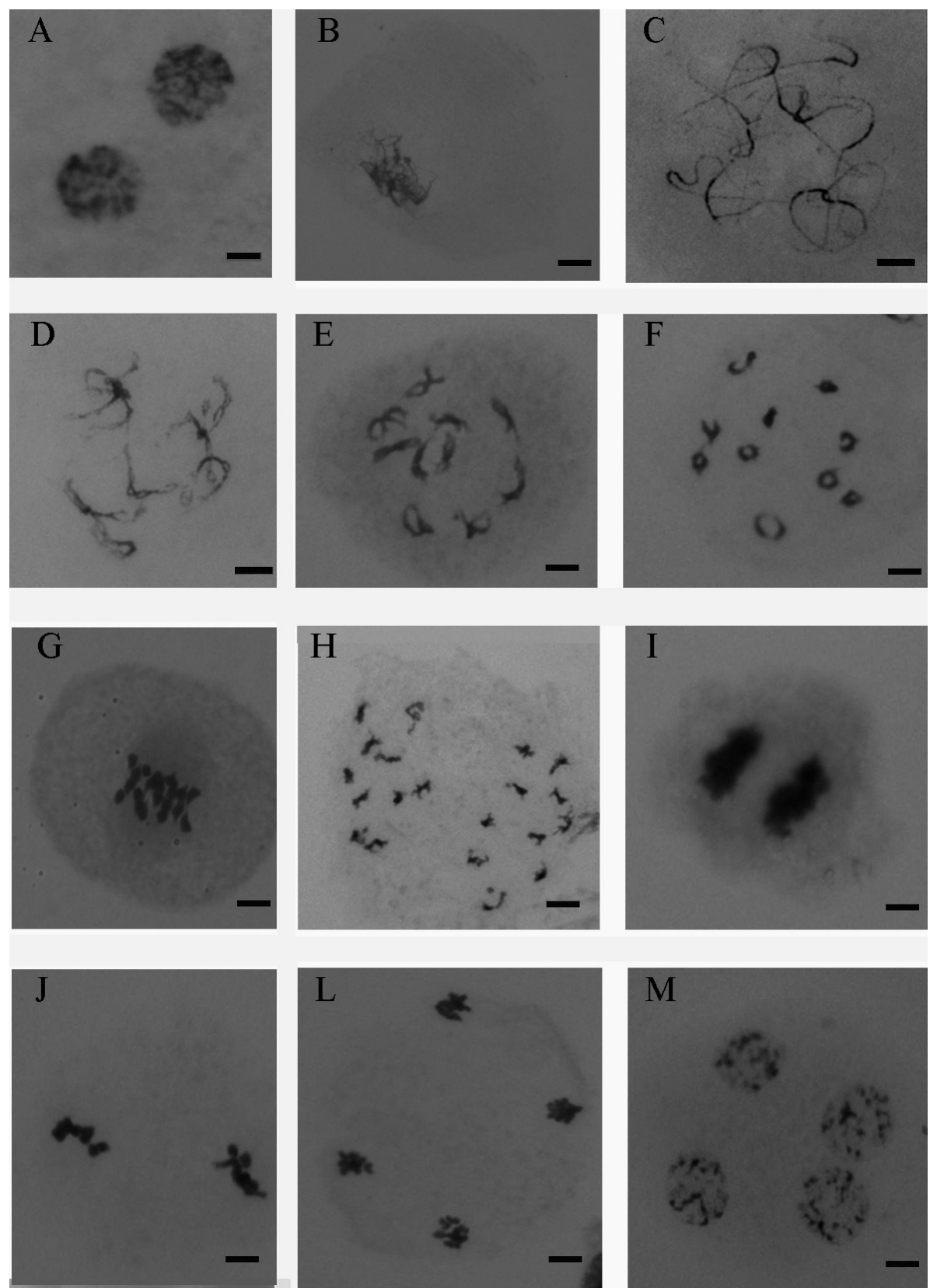

Fig. 1 - Meiosis of Heteropterys umbellata (A) Interphasic nucleus, (B) Zygotene, (C) Pachytene, (D) Initial diplotene, (E) Diplotene, (F) Diakinesis, (G) Metaphase I, (H) Anaphase I, (I) Telophase I, (J) Metaphase II, (L) Anaphase II, (M) Telophase II. Barr $=5 \mu \mathrm{m}$.

$3.31 \%$ of cells with early segregation were observed. We didn't observe chromosome alterations in meiosis II.

Regarding the meiotic products, the Alexander solution indicated high pollen viability in $H$. umbellata $(93.30 \%)$. It was also possible to observe that non-viable pollens were smaller than the viable ones (Fig. 2 E-F).
Heterochromatin QUALITY AND DistribUtion

The meiotic chromosomes of $H$. umbellata, mainly during pachytene, showed naturally large, blocks of chromatin around the centromers strongly stained with Giemsa (Fig. 1C). These same regions, after a C-banding treatment, showed positive stained indicating that 

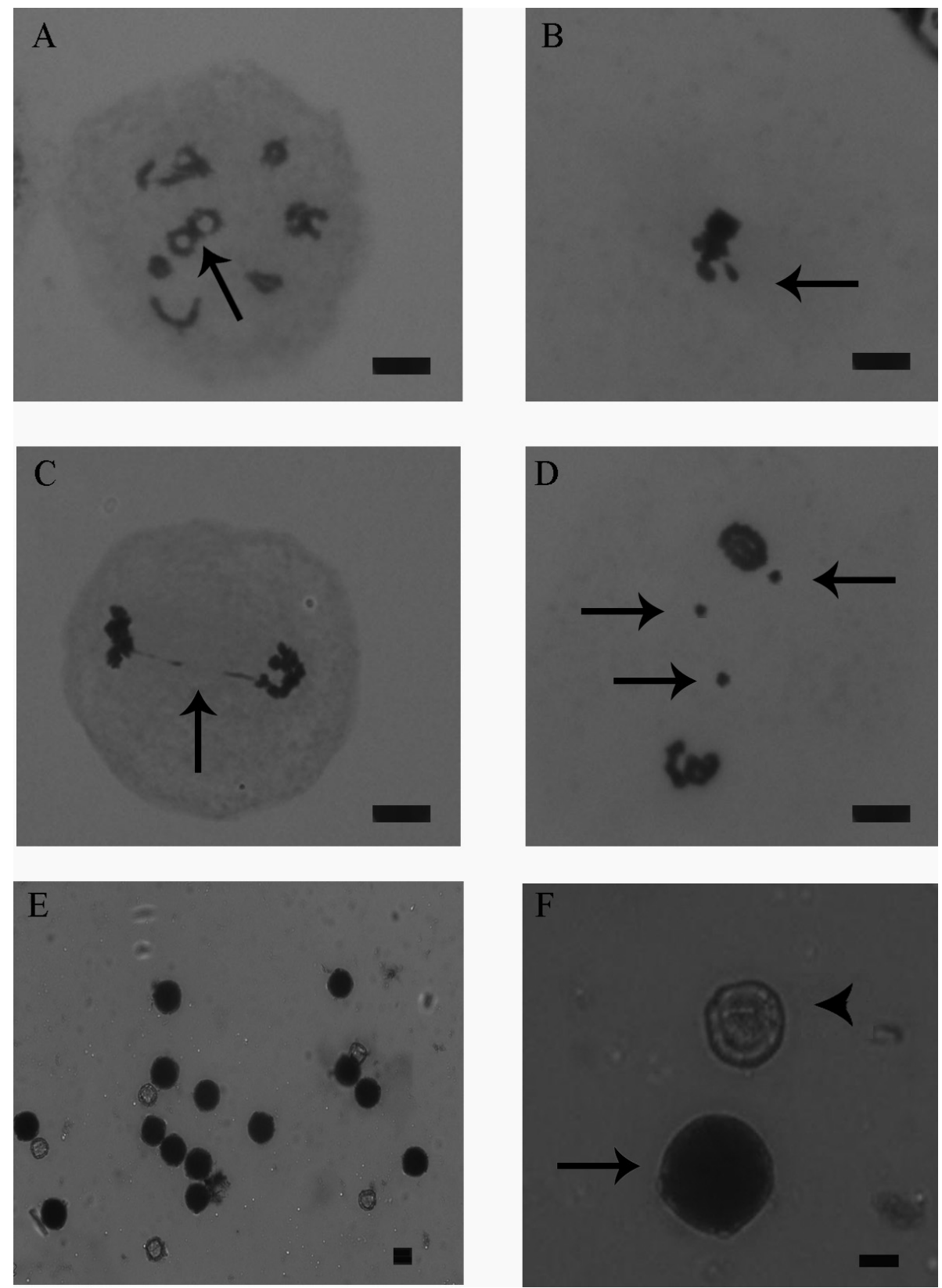

Fig. 2 -(A) Diakinesis with translocation (arrow), (B) Metaphase I with early segregaton (arrow), (C) Anaphase I with chromosome bridge (arrow), (D) Anaphase I with laggard chromosomes (arrows), (E) Pollen staining with Alexander solution, (F) Alexander staining: viable pollen (arrow) and non-viable pollen (arrow head). Barr $=5 \mu \mathrm{m}$.

these great blocks are rich in constitutive heterochromatin (Fig. 3A). In addition, when the slides were treated with DAPI and $\mathrm{CMA}_{3}$ (specific stains to detect heterochromatin blocks rich in AT and CG, respectively), we observed that the great heterochromatic blocks around the centromers were $\mathrm{DAPI}^{+}$, while for $\mathrm{CMA}_{3}$ only one positive mark was observed at a subterminal region of one bivalent pachytene, diplotene and diakineses. During the pachytene and diplotene we observed a unique mark probably due to the great proximity of the chromosomes in these stages, while on diakineses we observed two marks, each one at one of the two homo- 
logues of the same chromosome, and at the same position (Figs. 3 B-G and M). Regarding the interphase nucleus, the species showed great blocks of chromatin well distributed. When the nuclei were stained sequentially with DAPI and $\mathrm{CMA}_{3}$, the blocks were positive for DAPI, while for $\mathrm{CMA}_{3}$ we observed only two positive marks (Fig. 3 J-L).

\section{NuCleolar ORganizer REgIONS (NORs)}

One chromosome pair attached to the nucleoli was observed with Giemsa stained in a great number of diakinesis cells, which indicates that, in $H$. umbellata, one pair of sites for NORs (rDNA 45S) are active and involved with the nucleolus formation. Moreover, we also observed that this site is subterminal in some pachytenes and diakinesis where one great attached nucleolus was observed (Fig. $3 \mathrm{H}-\mathrm{I}$ and N-O).

\section{PALYNOLOGY}

The pollen of $H$. umbellata showed apolar morphology, with subspheroidals grains, 6 porates with colpoids and rugulate exine with few psilate areas (Fig. 4 A-D). The diameters of grains, D1 $(25.19 \pm 1.89 \mu \mathrm{m})$ and D2 $(25.13 \pm 2.08 \mu \mathrm{m})$ were very similar. The mean of sexine was $1.92 \mu \mathrm{m}( \pm 0.56)$ and nexine $1.33 \mu \mathrm{m}( \pm 0.39)$. The pollen stained was positive for Lugol and negative for Sudan, which indicates high starch content (Fig. 4 E-F). Regarding the apertures, the mean of pore diameter and the colpoidi size were $2.80 \mu \mathrm{m}( \pm 0.85)$ and $8.91 \mu \mathrm{m}( \pm 1.55)$, respectively. The margin of pores was thick and the colpoids were ever associated with the pores (Fig. 4D and G-H).

\section{DISCUSSION}

In all sexually reproducing organisms, meiosis is a complex process that helps to keep the chromosomal number constant from generation, to generation and ensures the operation of Mendel's laws of heredity (Singh 1993, Wendel 2000). The present study allowed us to determine, for the first time, the chromosome number of $H$. umbellata as $2 \mathrm{n}=20$, corroborating the hypothesis of Anderson (1990) that suggests the basic chromosome number for the genus $\mathrm{x}=10$.

The analysis of $H$. umbellata meiotic behavior showed that chromosome pairing was regular, and most of the cells showed 10II, although some irregularities such as chromosome bridges, translocations, early segregation and laggard chromosomes have been observed during the meiosis I. On the other hand, the high pollen viability that was observed can be a consequence of the checkpoint or nuclear restitution events during meiosis in H. umbellata, considering that the percentage of cells with laggard chromosomes observed in metaphase I and telophase II was, respectively, $11.20 \%$ and $0 \%$. About these checkpoints, there are at least three known mechanisms that can act in meiosis: the first one is called "DNA damage checkpoints pathway" that causes arrest of cells to either $G_{1}$ or $G_{2}$ stage of the cell cycle (Weinert 1998); the second one states that recombination events can be completed before metaphase I start, while the third one states that all the chromosomes can be attached to the spindle fibers during metaphase I (Shaw and Moore 1998). However, we cannot explain the exact mechanism that works in H. umbellata. One or all of them can act in order to correct eventual disturbances and assure the normal development of pollen grain.

Regarding the pollen viability, we observed that Alexander solution was very useful, fast and practice to access it. Pollen viability has been carried out by different stains such as carmine (Pagliarine 2000), lugol (Johansen 1940), fluorescein diacetate (Heslop-Harrison et al. 1984, Shivanna and Rangaswamy 1992) and tetrazolium salts (Hauser and Morrison 1964). In the present study the Alexander solution was used because it provides a good contrast between the wall and cytoplasm, which allows a better visualization of the unviable grains. The non-viable pollen grains were smaller than the normal ones which suggests a problem during pollen formation after meiosis. Similar results were also observed by Souza et al. (2003) in Passiflora edmundoi, and by Palma-Silva et al. (2008) in Vriesea gigantea.

Due to the very low viability of the seeds that hinder the study of mitotic chromosomes, the present description of meiotic process provides an important information about the species. The banding pattern showed here was the first report for Heteropterys species. In H. umbellata, there are great blocks of heterochromatin revealed by $\mathrm{C}$-banding technique, mainly around the centromere. This characteristic has been described for a great number of species but has not been 

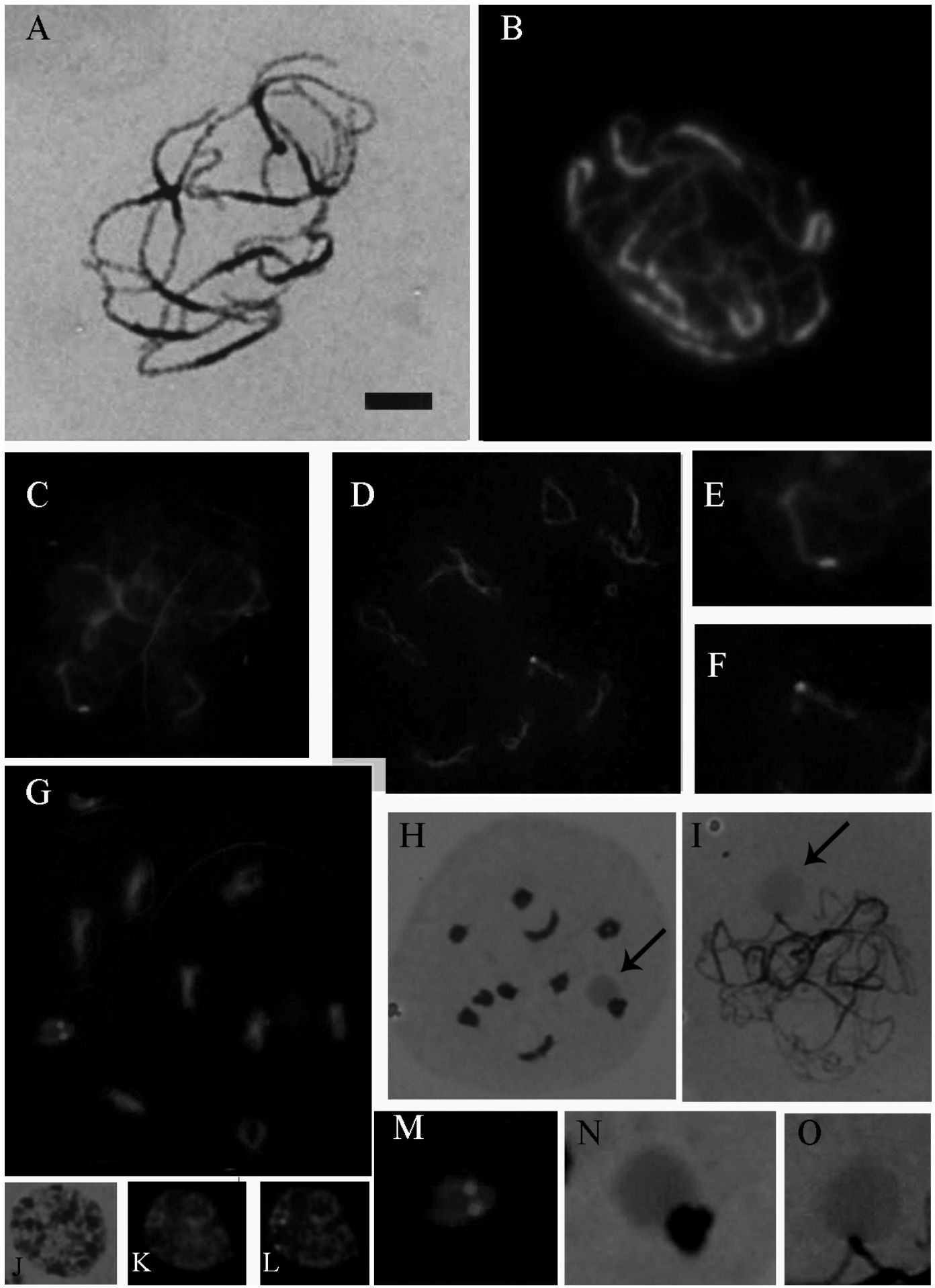

Fig. 3 - (A) Pachytene C-banded, (B) Pachytene DAPI stained showing positive marks around the centromers, (C) Pachytene stained with $\mathrm{CMA}_{3}$, (D) Diplotene stained with $\mathrm{CMA}_{3}$, (E) Detail of the positive $\mathrm{CMA}_{3}$ mark onto pachytenic chromosome, (F) Detail of the $\mathrm{CMA}_{3}$ positive mark onto diplotenic chromosome, $(\mathrm{G})$ Diakinesis stained with $\mathrm{CMA}_{3},(\mathrm{H})$ Diakinesis with one chromosome pair attached to the nucleolus (arrow), (I) Pachytene with one chromosome pair attached to the nucleolus (arrow), (J, K, L) Interphasic nucleus stained with Giemsa, DAPI and CMA 3 (see two positive marks), (M) Detail of $\mathrm{CMA}_{3}$ positive marks onto the chromosomes at diakinesis, $(\mathrm{N}, \mathrm{O})$ Details of nucleolus attached to one chromosome pair during the diakinesis and pachytene, respectively. Barr $=5 \mu \mathrm{m}$. 

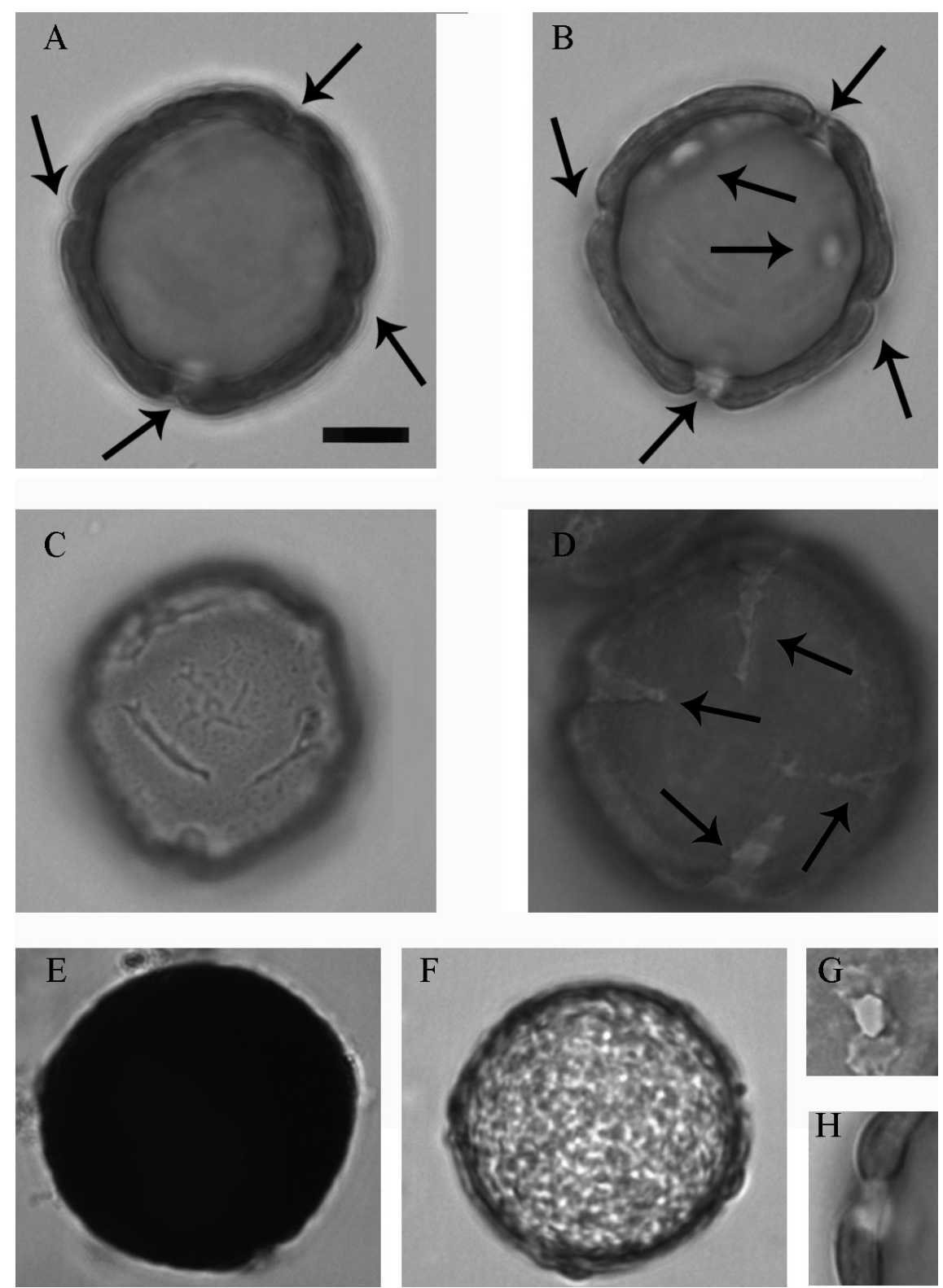

Fig. 4 - Acetolyzed pollen grains of H. umbellata, (A) Vision of 4 apertures (arrows), (B) Vision of 6 apertures (arrows), (C) Vision of exine, (D) Vision of colpoids (arrows), (E) Starch positive grain stained with Lugol, (F) Lipid negative grain stained with Sudan IV, (G-H) Details of pores. Barr $=5 \mu \mathrm{m}$.

reported earlier for Malpighiaceae (Brandão et al. 2007, Sousa et al. 2009). The heterochromatin is considered one of the most important factors in the evolution process (Edelman and Lin 1995) once it can interfere in many other mechanisms such as DNA replication, chromosomal structure, gene expression and the cell cycle (Redi et al. 2001, Stace 2000). Besides, variations in heterochromatin amounts have proved to be useful in karyosystematic and phylogenetic studies (Grif 2000, Sousa et al. 2009, Schwarzacher et al. 1980). Many studies indicate that the presence of few heterochromatin in one species is a plesiomorphic condition, while large blocks indicate an apomorphic condition (Greilhuber 1979, Redi et al. 2001). 
The fluorochrome bandings were also very important to access the heterochromatin constitution of H. umbellata. The large positive blocks visualized by DAPI indicated that the species possesses large amounts of AT and few amounts of GC. This conclusion was also supported by the single positive signal observed after $\mathrm{CMA}_{3}$ staining. Nevertheless, the association among $\mathrm{CMA}_{3}$ marks (only one pair), their chromosome places (terminal regions) and the number of chromosomes attached to the nucleoli (only one pair) clearly indicated that the $H$. umbellata possesses only one chromosome pair with active sites for nucleolus organization. Schweizer (1976) described the relationship between GC specific stain and NORs (Nucleolar Organizer Regions) also using the $\mathrm{CMA}_{3}$ positive bands. Sousa et al. (2009) also observed in Lippia alba (Verbenaceae) two pairs of chromosomes attached to one nucleolus, and $\mathrm{CMA}_{3}$ marks at the same place of NORs. In addition, they observed by AgNOR banding that only one of these two pairs of chromosomes had active NORs sites, although the FISH technique had shown three pairs of NORs.

In addition to the cytological studies we also observed that pollen grains of $H$. umbellata are very similar to other species of Malpighiaceae, including species of the genus Heteropterys. Gonçalves-Esteves et al. (2007) described the pollen morphology of 5 species of Heteropterys, and reported that the diameter sizes (D1 and D2) ranged from D1 $=27.1 \mu \mathrm{m}$ and D2 $=27.8 \mu \mathrm{m}$ in $H$. rufula to D1 $=49.1 \mu \mathrm{m}$ and D2 $=45.3 \mu \mathrm{m}$ in $H$. coleopteran. According to the diameter of the grains, the authors classified the studied species as small and median pollen grains, respectively. Our results were very similar to those ones observed to $H$. rufula. Using the same system, the values of D1 $=25.19 \mu \mathrm{m}$ and $\mathrm{D} 2=25.13 \mu \mathrm{m}$ allowed us to classify the pollen grains of $H$. umbellata as small ones. On the other hand, regarding the pore diameter, we observed different results if they are compared with other Heteropterys species. While we observed a mean value of pore diameter equal to $2.80 \mu \mathrm{m}$, Gonçalves-Esteves et al. (2007) observed values that ranged from 5.80 to $7.30 \mu \mathrm{m}$. With respect to exine ornamentation and thickness, the present results were very similar to those ones observed by GonçalvesEsteves et al. (2007) for other 5 species.
Concerning the chemical content of pollens from H. umbellata, it may be stated that this species has pollen grains that are rich in starch due to positive stained with Lugol and negative one with Sudan solution. Baker and Baker (1979) argued that starch pollen arose as an adaptation to deter pollen theft by non-pollinating insects, and lipid pollen arose as a plant adaptation to attract and reward pollen-feeding pollinators. There are no reports about the pollination in the genus Heteropterys. Our results about the pollen content suggest, according to Baker and Baker's hypothesis, that pollinators of $H$. umbellata are possibly non-pollen-feeding pollinators as wings, birds, moths and other animals that prefer nonstarch pollen. Nevertheless, additional studies about the pollination systems in Heteropterys should be done to better understand how this system works.

Finally, our data constitute an important upgrade in the biology of the genus Heteropterys, and can be used to future taxonomic and phylogenetic studies. The use of the same approach with of other species will also be very interesting.

\section{ACKNOWLEDGMENTS}

The authors thank Fundação de Amparo à Pesquisa do Estado de Minas Gerais (FAPEMIG), Coordenação de Aperfeiçoamento de Pessoal de Nível Superior (CAPES) and Conselho Nacional de Desenvolvimento Científico e Tecnológico (CNPq) for the financial support.

\section{RESUMO}

O gênero Heteropterys é um dos maiores gêneros entre as Malpighiaceae. Entretanto, poucos estudos citológicos e palinológicos foram relatados. O presente trabalho descreveu pela primeira vez o número cromossômico, o padrão heterocromático, o comportamento meiótico, a viabilidade polínica e aspectos palinológicos de Heteropterys umbellata, uma espécie muito disseminada. Uma grande população brasileira foi estudada utilizando técnicas convencionais para o estudo de cromossomos meióticos e acetólise para acessar a morfologia polínica. A espécie apresentou $2 \mathrm{n}=20$ cromossomos, desenvolvimento meiótico normal e pólens viáveis. Grandes blocos de heterocromatina foram observados ao redor dos centrômeros. A coloração com DAPI foi positiva para a heterocromatina centromérica, enquanto marcas com $\mathrm{CMA}_{3}$ foram observadas somente em um sítio terminal de um par de cro- 
mossomos homólogos. Este resultado e a presença de um par de cromossomos associados a um nucléolo durante o paquíteno e diacinese sugerem a presença de somente um par de RONs. A análise palinológica revelou que os grãos de pólen são apolar, com 6 poros e colpóides associados a todos eles. O conteúdo polínico foi positivo para o teste de amido e a exina mostrouse rugulada com poucas regiões psiladas.

Palavras-chave: número cromossômico, padrão heterocromático, Heteropterys umbellata, Malpighiaceae, meiose, viabilidade polínica.

\section{REFERENCES}

ALEXANDER MP. 1980. A versatile stain for pollen fungi, yeast and bacteria. Stain Tech 55: 13-18.

AMORIM AM. 2002. Five new species of Heteropterys. Malpighiaceae) from Central and South America. Brittonia 54: $217-232$.

ANDERSON WR. 1990. Notes on Neotropical Malpighiaceae - III. Contrib Univ Mich Herb 17: 39-54.

ANDERSON WR. 1993. Chromosome number of Neotropical Malpighiaceae. Contrib Univ Mich Herb 19: 341354.

ANDERSON WR AND DAVIS CC. 2007. Generic adjustments in Neotropical Malpighiaceae. Contrib Univ Mich Herb 25: $137-166$.

BAKER HG AND BAKER I. 1979. Starch in angiosperm pollen grains and its evolutionary significance. Amer J Bot 66: 591-600.

Boff T And Schifino-Wittmann MT. 2002. Pollen fertility and meiotic behaviour in accessions and species of leucaena. Trop Grassl 36: 54-58.

Brandão AD, Viccini LF, Salimena FRG, Vanzela ALL AND ReCCO-Pimentel SM. 2007. Cytogenetic Characterization of Lippia alba and Lantana camara (Verbenaceae) from Brazil. J Plant Res 120: 317-321.

Briggs D AND WALters SM. 1997. Plant variation and evolution, $3^{\text {rd }}$ ed., Cambridge: Cambridge University Press.

EDELMAN JR AND LIN YJ. 1995. Repetitive DNA heterochromatin: can it be the "driving force" of evolution and speciation? Cytobios 83: 117-127.

ERdtMan G. 1960. The acetolysis method. A revised description. Sven Bot Tidskr 54: 561-564.

Galietta G, Giuliane G, Loizzo A, Amat AG, FumaGalli E, Feo VD, Quaranta E, Paladino L And CAPAsso A. 2005. Neurophysiological studies of Hete- ropteris glabra Hok. \& Arn. (Malpighiaceae) in DBA/2J mice. J Ethnopharmacol 97: 415-419.

Gonçalves-Esteves V, Junior EFS And MendonçA CBF. 2007. Palinologia de espécies de Malpighiaceae Juss. ocorrentes nas restingas do Estado do Rio de Janeiro. Hoehnea 34: 519-529.

Goodwillie C. 2000. Inbreeding depression and mating systems in two species of Linanthus (Polemoniaceae). Heredity 84: 283-293.

Greilhuber J. 1979. C-band distribution, DNA content, and basic composition in Ardoxa maschatellina (Ardoxaceae), a plant with cold sensitive chromosomes segments. Plant Syst Evol 129: 63-109.

GRIF VG. 2000. Some aspects of plant karyology and karyosystematics. Int Rev Cytol 196: 131-175.

GUERRA M. 2008. Chromosome numbers in plant cytotaxonomy: concepts and implications. Cytogenet Genome Res 120: 339-350.

HAuser EJP ANd MorRison JH. 1964. Cytochemical reduction of nitroblue-tetrazolium as an index of pollen viability. Am J Bot 51: 748-753.

HESLOP-HARRISON J, HESLOP-HARRISON Y AND SHIVANNA KR. 1984. The evolution of pollen quality and a further appraisal of the fluorochromatic (FCR) test procedure. Theor Appl Genet 67: 367-375.

HusBAND BC AND SCHEMSKE DW. 1996. Evolution of the magnitude and timing of inbreeding depression in plants. Evolution 50: 54-70.

JOHANSEN DA. 1940. Plant microtechnique. McGraw Hill, New York.

Kokubugata G and Katsuhiko KFLS. 1996. Diferential fuorescent-banding patterns in chromosomes of four species of Cycas (Cycadaceae). Bot J Linn Soc 120: 5155.

KREBS SL AND HANCOCK JF. 1990. Early-acting inbreeding depression and reproductive success in the highbush blueberry, Vaccinium corymbosum. Theor Appl Genet 79: $825-832$.

LOMBELlo RA AND FORNi MER. 2001. Cytological studies on Banisteriopis C.B. Robison ex Small and Heteropterys Kunth (Malpighiaceae). Cytologia 66: 253-259.

ORMOND WT, Silva MIA AND CASTElls ARL. 1981. Contribuição ao estudo citológico de Malpighiaceae. I. Número de cromossomos. Arch Jard Bot 25: 169-173.

PAGLIARINI MS. 2000. Meiotic behavior of economically important plant species: the relationship between fertility and male sterility. Genet Mol Biol 23: 997-1002. 
PAL M. 1964. Chromosome numbers in some Indian angiosperms I. Proc Indian Acad Sci 5: 347-350.

Palma-Silva C, Paggi CM, Felicetti RA, Ferraz R, KaltchuK-SAntos E, Bered F and BodaneseZANETTINI MH. 2008. Meiotic behavior and pollen viability of wild populations of the neotropical species Vriesea gigantea (Bromeliaceae). Plant Species Biol 23: 217-221.

Punt W, Hoen PP, Blackmore S, Nilsson S AND Thomas AL. 2007. Glossary of pollen and spore terminology. Rev Palaeobot Palynol 143: 1-81.

REDi CA, GARAGNA S, ZaCharias H, ZuCCOTTI M AND CAPANNA E. 2001. The other chromatin. Chromosoma 110: $136-147$.

Schwarzacher T, Ambros P AND SchweIzer D. 1980. Application of Giemsa banding to orchid karyotype analysis. Plan Syst Evol 134: 293-297.

SCHWEIZER D. 1976. Reverse fluorescent chromosome banding with chromomycin and DAPI. Chromosoma 58: 307-324.

SEMPLE JC. 1970. In chromosome number of phanerogam 4. Ana Miss Bot Gard 57: 382-384.

SHAw P AND Moore G. 1998. Meiosis: vive la defference! Curr Opin Plant Biol 1: 458-462.

SHIVANNA KR AND RANGASWAMY NS. 1992. Pollen biology: a laboratory manual. Springer-Verlag, Berlin.
SINGH RJ. 1993. Plant cytogenetics. CRC Press. Boca Raton. Sousa SM, SILVA PS, TORRES GA AND ViCCINI LF. 2009. Chromosome banding and essential oils composition of Brazilian accessions of Lippia alba (Verbenaceae). Biologia 64: 711-715.

Souza MM, Pereira TNS, Viana AP, Pereira MG, BERNACCI LC, Sudré CP AND Silva LC. 2003. Meiotic irregularities and pollen viability in Passiflora edmundoi Sacco (Passifloraceae). Caryologia 56: 161-169.

StACE CA. 2000. Cytology and cytogenetics as a fundamental taxonomic resource for the $20^{\text {th }}$ and $21^{\text {st }}$ centuries. Taxon 49: 451-477.

StebBins GL. 1971. Chromosomal evolution in higher plants. London: Edward Arnold.

Viccini lf, Pierre PMO, PraÇa MM, Costa DCS, Romanel EC, Sousa SM, PeiXoto PHP AND SALIMENA FRG. 2005. Chromosome numbers in the genus Lippia (Verbenaceae). Plant Syst Evol 256: 171-178.

WEINERT T. 1998. DNA damage checkpoints update: getting molecular. Curr Opin Genet Dev 8: 185-193.

Wendel JF. 2000. Genome evolution in polyploids. Plant Mol Biol 42: 225-249.

WiLlis JH. 1993. Effects of different levels of inbreeding on fitness components in Mimulus guttatus. Evolution 47: 864-876. 